\section{Consequences of geographical habitats on population struc- ture and genetic diversity in Campanula spp.}

\author{
Matteo Caser,' Valentina Scariot,' \\ Paul Arens ${ }^{2}$ \\ 'Department of Agronomy, Forest and \\ Land Management, University of Turin, \\ Grugliasco (TO), Italy; \\ 2Plant Research International (PRI), \\ Wageningen, The Netherlands
}

\begin{abstract}
Characterization of populations by means of DNA techniques provides a tool for precise identification and a quantitative estimate of genetic diversity, crucial in evaluation of genetic fragmentation within and among populations. NBS profiling are PCR-based approaches that sample genetic variation in resistance genes (R-gene), and $\mathrm{R}$ gene analogs (RGA). To date, myb patterns have not been used for evaluating genetic diversity in other species. NBS primers are homologous to the conserved sequences in the NucleotideBinding-Site of the NBS-LRR class of R-genes. A total of 12 populations from five Campanula species (C. barbata L., C. latifolia L., C. rapunculoides L., C. spicata L. and $C$. trachelium L.), autochthonous of the West Italian Alps, were genotyped via nucleotide-binding site (NBS) and $m y b$ gene profiling. The selected markers produced a total of 361 bands, showing high levels of polymorphism. Genetic diversity among and within species and population structure was evaluated by different statistical analyses performed using TREECON software, Mantel Nonparametric Test, NTSYS package, AMOVA and STRUCTURE. The correlation between genetic variability and geographical location suggests that the five Campanula species have been subjected to long-term evolutionary processes consistent with the natural fragmentation of continuous mountains areas.
\end{abstract}

\section{Introduction}

The genetics of species whose preservation is of great importance for biodiversity maintenance has been of heightened interest to evolutionary and conservation biologists in the 21st century. ${ }^{1}$ In particular, in conservation studies, an important topic is the evaluation of genetic fragmentation within and among populations. The spatial distribution of genetic diversity in populations is function of gene flow, mutation, inbreeding, population size, and social organization, and has been modelled by biological, ecological, and historical factors related to geo-climatic events. ${ }^{2.4}$ Over the last few decades, the study and safeguarding of genetic variation in nature for plastic responses has progressed significantly.-8

Campanula L species might be considered genetic resources able to persist under a wide range of ecological conditions. ${ }^{9}$ In fact, their habitat can vary considerably, from seashore to very high altitude, with colonies found in all major environments from forests to grasslands, and even in rocks.

In the West Italian Alps, five species deserve highlighting above others: 1) C. barbata L. (2n $\left.=34:{ }^{10}\right)$, a hairy short-lived perennial or biennial plant, growing in dry grassland on the siliceous soils of the alpine regions of central and boreal Europe; 2) C. latifolia Brantwood $\left(2 \mathrm{n}=34{ }^{11}\right)$, a perennial plant originating from Northern Europe, growing in acidic soils and forests in the Italian Alps and Northern Apennines; 3) C. rapunculoides $\mathrm{L}$. $(2 \mathrm{n}=68 ; 2 \mathrm{n}$ $=102 ;{ }^{12,13}$ ), a perennial plant, growing on stony and wooded areas of Europe, except for the arctic regions and islands; 4) C. spicata L. (2n $=34 ;^{12}$ ), a perennial plant, growing on stones and cliffs and widespread in the Italian Alps and Northern Apennines; and 5) C. trachelium L. $\left(2 \mathrm{n}=34 ;{ }^{14}\right)$, a perennial species native to Europe, from England, throughout the Mediterrean basin, to Northern Africa. ${ }^{15}$

Molecular studies may prove useful in improving spatial genetic variation knowledge and for delineating evolutionary genetic processes. ${ }^{16-19}$ Neutral markers such as amplified fragment length polymorphisms (AFLP ${ }^{20}$ ) or simple sequence repeats $\left(\mathrm{SSR}^{21,22}\right.$ ) are commonly used to screen collections. In previous studies, the diversity and the structure in the genus Campanula was studied using nuclear (ISSR) and chloroplast (cpSSR) markers in $C$. pollinensis Podlech and $C$. pseudostenodon Lac. ${ }^{4}$ suggesting that the genetic differentiation between subpopulations was caused by a restricted gene flow.

Recently, nucleotide-binding site (NBS) and myb gene profiling techniques have been assessed in various genetic approaches. NBS profiling is a PCR-based methodology for studying genetic variability that specifically targets NBS-TIR resistance genes and R-gene analogs by using a degenerate primer based on conserved motifs of these genes. ${ }^{23}$ This technique has already been used in apple, ${ }^{24}$ lettuce, ${ }^{25}$ potato, barley, durum wheat, and cauliflower ${ }^{23,26,27}$ to map genes related to disease resistance (up to $95 \%$ of the amplified bands relate to RGAs). MYB proteins constitute a class of DNA binding proteins, which is particularly important for transcriptional regulation in plants. ${ }^{28}$ This protein family is characterized
Correspondence: Matteo Caser, Department of Agronomy, Forest and Land Management, University of Turin, via L. da Vinci 44, 10095 Grugliasco (T0), Italy.

E-mail: matteo.caser@unito.it

Key words: NBS profiling, myb profiling, campanula, genetic typing.

Acknowledgments: we thank all the staff of the Unito-Floriculture unit for helping collect samples and Hanneke van der Schoot and all the staff of the Plant Breeding Department (Plant Research International-University of Wageningen) for assistance in NBS and myb profiling.

Authors' contributions: MC, main contributor to conception and design, acquisition, analysis, and interpretation of data. VS, critical revision.

PA, substantial contributions to conception of the data and final approval of the version to be published. The Authors report no conflicts of interest.

Received for publication: 8 September 2009 Revision received: 18 December 2009 Accepted for publication: 28 December 2009

This work is licensed under a Creative Commons Attribution 3.0 License (by-nc 3.0).

(C) Copyright M. Caser et al., 2010

Licensee PAGEPress, Italy

International Journal of Plant Biology 2010; 1:e5 doi:10.4081/pb.2010.e5

by having a structurally conserved DNA binding domain - the MYB DNA binding domain which contains one (I), two (II), or three (III) imperfect repeats. The two-repeat (R2R3) MYB family is the most commonly identified in plants and consists of 125 members in Arabidopsis. ${ }^{29}$ The known functions of plant MYB proteins include the regulation of secondary metabolism, control of cellular morphogenesis, and regulation of the meristem and the cell cycle. ${ }^{30}$

In the present research, we evaluated NBS and myb profiling in Campanula as tools for genetic diversity studies, which we used to investigate the i. genetic variations, and ii. population structures in five species (C. barbata, C. latifolia, C. rapunculoides, $C$. spicata and C. trachelium).

\section{Materials and Methods}

\section{Plant material}

We sampled a total of 12 populations belonging to $C$. barbata, C. latifolia, $C$. rapunculoides, C. spicata and $C$. trachelium (Table 1) in the West Italian Alps (Figure $\mathbf{1}^{31}$ ). The sampling 
Table 1. Sampled Campanula species and populations with their identification code (ID), geographical location, soil, latitude (La.), longitude (Lo.), altitude (Al.) and sample size (n).

\begin{tabular}{|c|c|c|c|c|c|c|c|}
\hline ID & Species & Location & Soil (substrate) & La. (N) & Lo. (E) & Al. (m) & $\mathrm{n}$ \\
\hline Rapl & C. rapunculoides & Gesso Valley & grassland & $44^{\circ} 15^{\prime} 29.65^{\prime \prime}$ & $7^{\circ} 23^{\prime} 04.30^{\prime \prime}$ & 830 & 6 \\
\hline Rap2 & C. rapunculoides & Gesso Valley & grassland & $44^{\circ} 18^{\prime} 02.66^{\prime \prime}$ & $7^{\circ} 27^{\prime} 19.47^{\prime \prime}$ & 719 & 6 \\
\hline Rap3 & C. rapunculoides & Vermenagna Valley & scrub & $44^{\circ} 14^{\prime} 06.03^{\prime \prime}$ & 7³1’49.34" & 980 & 4 \\
\hline Rap4 & C. rapunculoides & Troncea Valley & scrub & $45^{\circ} 01^{\prime} 30.61^{\prime \prime}$ & 704'23.04" & 1818 & 6 \\
\hline Latl & C. latifolia & Monferrato & grassland & $45^{\circ} 05^{\prime} 18.11 "$ & $8^{\circ} 02^{\prime 2} 2.21^{\prime \prime}$ & 447 & 3 \\
\hline Lat2 & C. latifolia & Sesia Valley & rockwall & $45^{\circ} 51^{\prime} 14.32^{\prime \prime}$ & $7^{\circ} 56^{\prime} 11.23^{\prime \prime}$ & 1203 & 6 \\
\hline Trachl & C. trachelium & Stura Valley & grassland & $44^{\circ} 20^{\prime} 39.48^{\prime \prime}$ & $7^{\circ} 01^{\prime} 55.99 "$ & 1245 & 6 \\
\hline Trach2 & C. trachelium & Monferrato & grassland & $45^{\circ} 06^{\prime} 32.29^{\prime \prime}$ & 801'30.11" & 410 & 6 \\
\hline Barb & C. barbata & Lanzo Valley & grassland & $45^{\circ} 21^{\prime} 55.22^{\prime \prime}$ & $7^{\circ} 20^{\prime} 25.26^{\prime \prime}$ & 1880 & 6 \\
\hline Spicl & C. spicata & Sesia Valley & rockwall & $45^{\circ} 49^{\prime} 54.28^{\prime \prime}$ & $7^{\circ} 57^{\prime} 24.20^{\prime \prime}$ & 1150 & 6 \\
\hline Spic2 & C. spicata & Sesia Valley & rockwall & $45^{\circ} 49^{\prime} 19.93^{\prime \prime}$ & $8^{\circ} 09^{\prime} 25.43^{\prime \prime}$ & 614 & 6 \\
\hline Spic3 & C. spicata & Varaita Valley & scrub & $44^{\circ} 33^{\prime} 58.33^{\prime \prime}$ & $7^{\circ} 21^{\prime} 06.96 "$ & 1812 & 6 \\
\hline
\end{tabular}

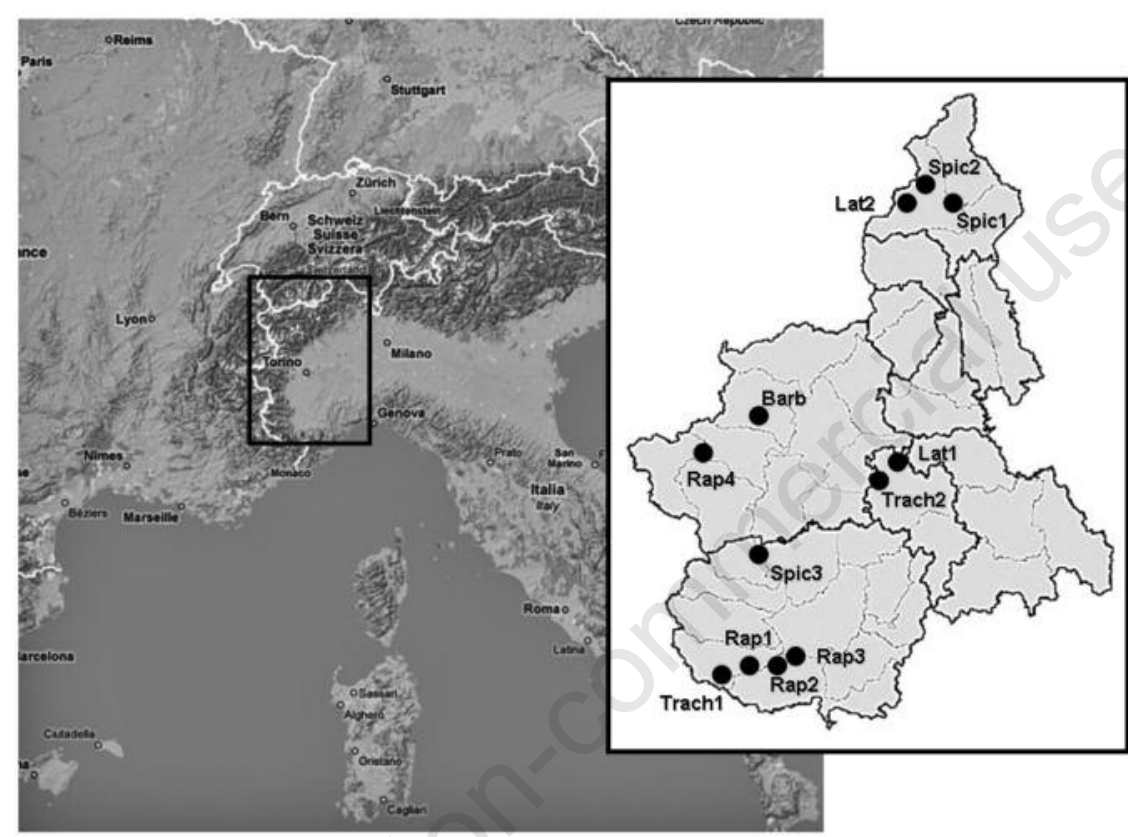

Figure 1. Sampling site distribution of the five Campanula species in Piedmont (Northern Italy).

areas ranged in size between $500 \mathrm{~m}$ and $6 \mathrm{~km}$; the distance between genotypes within populations ranged between $10 \mathrm{~cm}$ and $10 \mathrm{~m}$.

\section{DNA extraction and molecular analyses}

Total genomic DNA was extracted from freeze-dried leaves using the Dneasy Plant Mini Kit (QIAGEN, Santa Clarita, California, CA, USA) according to the manufacturer's instructions. At the end of the procedure, the columns were eluted twice with $100 \mu \mathrm{L}$ of $\mathrm{AE}$ buffer, after which they were stored at $-20^{\circ} \mathrm{C}$. Three different restriction enzymes (MseI, $R s a \mathrm{I}$ and HaeIII) and 10 primers (NBS1, NBS2,
NBS3, NBS5, NBS5a, NBS6, NBS7, NBS8, GLPL6 and MYB2 ${ }^{23}$ ) were used in a total of 33 primer-enzyme combinations.

The NBS profiling was applied according to the protocol described by van der Linden $e t$ al. ${ }^{23}$ with some modifications. Restriction digestion and adaptor ligation were performed in a single reaction by incubating $400 \mathrm{ng}$ of DNA overnight at $37^{\circ} \mathrm{C}$. Amplification of NBS-specific fragments was achieved through a two-step PCR as described in the original protocol. ${ }^{23}$ The first (linear) PCR reaction $(5 \mu \mathrm{L}$ of restriction-ligation template, $2.5 \mu \mathrm{L}$ of PCR buffer, $1 \mu \mathrm{L}$ of $5 \mathrm{mM}$ dNTP, $0.08 \mu \mathrm{L}$ of HotstarTaq polymeraseQiagen, $2 \mu \mathrm{L}$ of $10 \mathrm{pmol} / \mathrm{uL}$ NBS-specific primer and adapter primer in a final volume of $25 \mu \mathrm{L}$ ) was performed in a PTC-200 thermocycler (MJ Research) using the following thermal profile: $15 \mathrm{~min}$ at $95^{\circ} \mathrm{C}$ to activate HotStarTaq polymerase, 35 cycles with $30 \mathrm{~s}$ at $95^{\circ} \mathrm{C}$ for denaturing, $1 \mathrm{~min}$ and $40 \mathrm{~s}$ at $55^{\circ} \mathrm{C}$ (GLPL6, MYB2 and all the NBS primers except NBS2) or $60^{\circ} \mathrm{C}$ (NBS2) for annealing and $2 \mathrm{~min}$ at $72^{\circ} \mathrm{C}$ for extension and a final extension at $72^{\circ} \mathrm{C}$ for 20 min at the end of the cycles. The linear PCR was followed by an exponential PCR with NBS/myb primer and an adapter primer fluorescent labeled with IRD 700 or IRD 800 by adding to the linear PCR product $10 \mathrm{pmol} / \mathrm{\mu L}$ of each primer, $2.5 \mathrm{mM}$ of dNTPs, $1 \mu \mathrm{L}$ Supertaq $10 \mathrm{X}$ PCR buffer and $5 \mathrm{U} / \mu \mathrm{L}$ supertaq polymerase in an end volume of $10 \mu \mathrm{L}$. The cycling program was performed for $15 \mathrm{~min}$ at $95^{\circ} \mathrm{C}$ and 20 cycles of $30 \mathrm{~s}$ at $94^{\circ} \mathrm{C}, 1 \mathrm{~min}$ and $40 \mathrm{~s}$ at $55^{\circ} \mathrm{C}$ or $60^{\circ} \mathrm{C}, 2 \mathrm{~min}$ at $72^{\circ} \mathrm{C}$ and a final extension at $72^{\circ} \mathrm{C}$ for $20 \mathrm{~min}$. For visualization, $10 \mu \mathrm{L}$ of LiCor formamide with loading dye was added to the PCR products. Samples were denatured for 3 min at $95^{\circ} \mathrm{C}$, cooled on ice and loaded on a $6 \%$ denaturing polyacrylamide gel using the Li-Cor IR2 Genetic Analyzer (LICOR Biosciences, Lincoln, NE USA).

\section{Data analysis}

We coded NBS and $m y b$ bands as present (1) or absent (0) for each plant, creating a binary data matrix.

Genetic distance were computed using the formula proposed by Nei et al. $.^{32} 1-2 x y / x+y$, where $x y$ is the number of shared bands by the pair and $x+y$ is the total number of bands of the pair. We performed the cluster analysis, applying Neighbor-joining, using arithmetic means ${ }^{33}$ with the TREECON software. ${ }^{34}$ By applying the same software, we estimated the statistical stability of the branches in the tree by bootstrap analysis with 1,000 replicates. Mantel analysis ${ }^{35}$ was conducted by using the Mantel Non -parametric Test Calculator for Windows, version 
Table 2. Number of unique banding patterns in the studied Campanula species obtained by means of myb and NBS primer-enzyme combinations. In brackets, the percentage of unique banding patterns per species is reported.

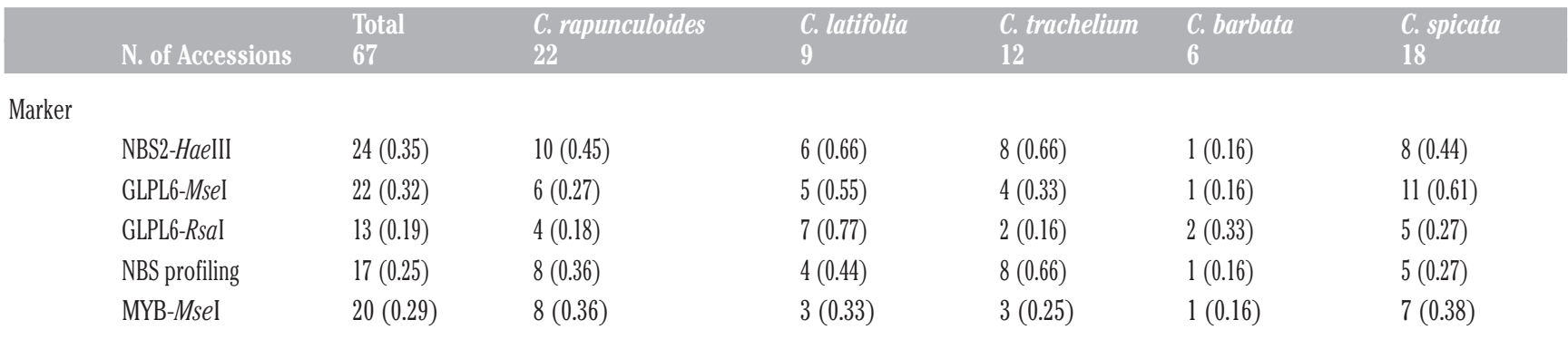

Table 3. Mean pairwise similarity matrix based on Nei and Li matrix between the five Campanula species performed on: (a) joined myb and NBS data, (b) myb data and (c) NBS data. In brackets the mean similarity values within the species.

a

\begin{tabular}{llllll} 
Species & C. rapunculoides & C. latifolia & C. trachelium & C. barbata & C. spicata \\
C. rapunculoides & $1(0.568)$ & & & & \\
C. latifolia & 0.314 & $1(0.521)$ & & & \\
C. trachelium & 0.352 & 0.283 & $1(0.510)$ & $1(0.676)$ & \\
C. barbata & 0.288 & 0.380 & 0.243 & 0.305 & $10.526)$ \\
C. spicata & 0.381 & 0.336 & 0.327 & \\
\hline
\end{tabular}

b

\begin{tabular}{|c|c|c|c|c|c|}
\hline Species & C. rapunculoides & C. latifolia & C. trachelium & C. barbata & C. spicata \\
\hline C. rapunculoides & $1(0.606)$ & & & & \\
\hline C. latifolia & 0.343 & $1(0.614)$ & & & \\
\hline C. trachelium & 0.382 & 0.295 & $1(0.548)$ & & \\
\hline C. barbata & 0.326 & 0.458 & 0.305 & $1(0.761)$ & \\
\hline C. spicata & 0.361 & 0.293 & 0.321 & 0.309 & $1(0.540)$ \\
\hline
\end{tabular}

c

\begin{tabular}{|c|c|c|c|c|c|}
\hline Species & C. rapunculoides & C. latifolia & C. trachelium & C. barbata & C. spicata \\
\hline C. rapunculoides & $1(0.564)$ & & & & \\
\hline C. latifolia & 0.324 & $1(0.424)$ & & & \\
\hline C. trachelium & 0.380 & 0.304 & $1(0.512)$ & & \\
\hline C. barbata & 0.309 & 0.339 & 0.291 & $1(0.688)$ & \\
\hline C. spicata & 0.399 & 0.349 & 0.368 & 0.325 & $1(0.509)$ \\
\hline
\end{tabular}

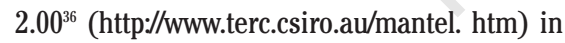
order to compare the matrices of the myb and NBS data. The significance of the statistic was evaluated by permutations (1000x) and expressed as a probability. ${ }^{37}$

We performed Principal Coordinate Analysis ( $\mathrm{PCoA})$ based on the estimated similarities. We plotted the first two axes according to the extracted Eigen vectors, using the software package NTSYS-pc version 2.1 (Applied Biostatistics Inc., NY, USA ${ }^{38}$ ).

We calculated the total genetic diversity in variance components among and within populations through the Analysis of Molecular Variance $\left(\mathrm{AMOVA}^{39}\right.$ ) with 1,000 permutations using AMOVA 1.5 package software.

The program STRUCTURE 2.2.3 based on a Markov chain Monte Carlo (MCMC) algo- rithm was used further to detect genetic stratification using the admixture model. ${ }^{40}$ Patterns of genetic structure in the 12 populations comprised from five Campanula species were analyzed in the entire data set with four separate runs at each $\mathrm{K}$ from 6 to 14. After preliminary analyses to determine the adequate burn-in and number of MCMC Reps generations, we decided to use a burnin period of 50,000 generations, a run length of 200,000 generations and 10 iterations at each $K$. We used a modal value of $\Delta K$ to assess the most likely $\mathrm{K}^{41}$ Specifically, we classified an individual into a cluster when the assignment probability was more than 0.75 . In other words, when an individual showed a color for more than three-quarters of its area, it was allocated to the correspon- ding population. When it did not, the genotypes displayed admixture, indicating gene flow between populations or even hybridization between species.

\section{Results}

\section{Level of polymorphism and discriminating capacity}

We tested three samples from each population against thirty-three primer-enzyme combinations. The generated fingerprints were evaluated for the overall clearness of the banding patterns. We selected four primer-enzyme combinations for further screening on 67 Campanula samples: GLPL6-MseI, GLPL6-RsaI, 


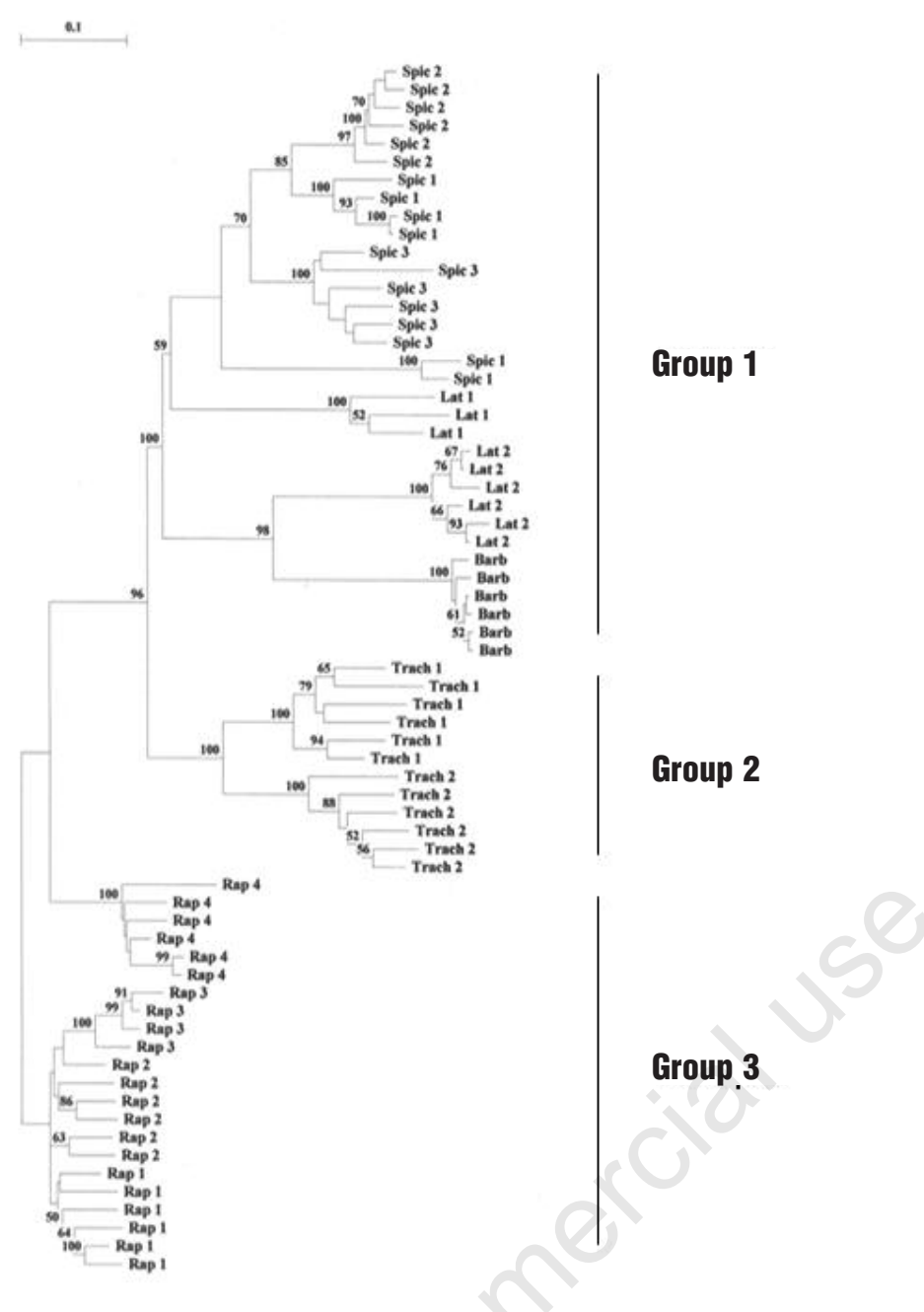

Figure 2. Consensus tree between Campanula populations and species for the presence/absence of the joined $m y b$ and NBS markers. Numbers at the internodes indicate bootstrap values from 1,000 re-sampling cycles.

NBS2-HaeIII and MYB2-MseI. We identified a total of 361 unambiguously scorable bands with the number of bands generated by each primerenzyme combination ranging from 47 (NBS2HaeIII) to 131 (MYB2-MseI), with an average of 90 polymorphic loci per combination.

In order to provide information on the differentiating capacity of each marker, we calculated the number of unique banding patterns per primer-enzyme combination (Table 2). In the 67 campanulas, the NBS and $m y b$ profiling primers produced a similar number of banding patterns, 17 and 20, respectively. Only in $C$. trachelium the number of banding patterns for NBS was more than double the value found for myb profiling. Among NBS markers, C. rapunculoides and $C$. trachelium were better discriminated by the combination of NBS2-HaeIII while $C$. latifolia and $C$. barbata were best by GLPL6-RsaI and C. spicata was best by GLPL6-MseI.

\section{Genetic diversity}

We used several approaches (AMOVA, Principal Co-ordinate Analysis, assignment test), comparing for consanguinity, to estimate the genetic diversity among and within species.

Between species, the mean similarity values (Ht) obtained by the joined NBS and myb data sets ranged from 0.243 (C. barbata and $C$. trachelium) to 0.381 (C. spicata and $C$. rapunculoides; Table $3 \mathrm{a}$ ). When myb profiling was used, the values ranged between $0.382(C$. rapunculoides and $C$. trachelium) and 0.293 (C. spicata and C. latifolia; Table $3 \mathrm{~b}$ ), and when NBS profiling was employed the values ranged between 0.399 (C. spicata and $C$. rapunculoides) and 0.291 (C. trachelium and C. barbata; Table 3c). Looking at the populations, the highest similarity values were obtained for all the molecular markers in $C$. rapunculoides
$(\mathrm{NBS}+m y b=0.578, m y b=0.618$ and NBS $=$ $0.596)$ while the lowest were found in $C$. latifolia $(\mathrm{NBS}+m y b=0.334, m y b=0.294$ and $\mathrm{NBS}=0.279$ ).

To compare the two molecular data sets (myb and NBS profiling), the Mantel test was performed. By means of a permutation procedure, the correlation between the two Nei and Li similarity matrices was tested against multiple randomizations of one of them. Results showed that the data were statistically correlated $(\mathrm{g}=27.204$, critical value $=1.645$ for $\mathrm{P}=$ $0.05, r=0.804)$. Consequently, to improve our understanding of these new molecular markers, NBS and myb profiling were evaluated both joined and as single data sets.

Cluster analysis with bootstrapping was applied to analyze the genetic relationships among the 67 genotypes by means of NBS and $m y b$ profiling combined data sets (Figure 2). The NJ tree derived from the joined data sets divided the samples into three distinct major groups. All populations of $C$. spicata, C. latifolia, and $C$. barbata were clearly grouped into the same branch (Group 1) and separated according to a high bootstrap value (100\%) from the second cluster comprised of the $C$. trachelium populations Trach1 and Trach2 (Group 2). Group 3, comprised of the $C$. rapunculoides genotypes, formed a cluster distinct from the other groups with very high bootstrap support (96\%). The tree also revealed a clear separation among populations within species, in accordance with their geographical provenance, except for $C$. spicata in where Spicl is scattered into two subgroups. Small differences in the clustering results, based on the myb and NBS data analyzed separately, were noted (trees not shown). Cluster analysis performed on the single $m y b$ gene profiling (data not shown) confirmed a $C$. trachelium cluster (Group 2); however, within the $C$. rapunculoides species genetic variability as high as in the NJ tree based on the combined markers (Group 3) were not revealed. The myb data set also showed a strong separation (100\%) of Barb and Lat2 from Group 1. In the dendrogram obtained from the NBS data (data not shown), Rap1, Rap2 and Rap3 populations were intermingled, yet clustered apart from Rap4, as shown in the combined tree. Whereas, in the same dendrogram, Spic3 and Trachl were grouped, based on high bootstrap values (96\% and $99 \%$, respectively), into the main cluster containing all samples derived from C. spicata, C. barbata, C. latifolia and $C$. trachelium.

To attribute the genetic variation distribution, a hierarchical AMOVA (Table 4) was performed on three sets: (a) myb, and (b) NBS patterns alone, and (c) combined myb-NBS profiling. The joined data set results showed highly significant differences $(\mathrm{P}=0.001$, determined from a 1,000 replication bootstrap) 
Table 4. Analysis of molecular variance among and within the five species and 12 populations of Campanula based on myb and NBS combined profiles (a) and NBS (b) and $m y b$ (c) alone. Levels of significance were based on 1000 interation steps (SS, sums of squares; MS, means squares; \%, proportion of genetic variability; P-value, level of significance).

a

\begin{tabular}{llllll} 
Level of variation & d.f. & SS & MS & P & \\
Among species & 4 & 1591.0 & 397.7 & 45.19 & 0.001 \\
Among populations within species & 7 & 711.4 & 209.3 & 32.54 & 0.001 \\
Within populations & 55 & 620.7 & 21.5 & 22.27 & 0.001 \\
\hline
\end{tabular}

b

\begin{tabular}{llllll} 
Level of variation & d.f. & SS & MS & P & \\
Among species & 4 & 917.7 & 229.4 & 26.55 & 0.001 \\
Among populations within species & 7 & 619.0 & 88.4 & 32.11 & 0.001 \\
Within populations & 55 & 925.1 & 16.8 & 41.34 & 0.001 \\
\hline
\end{tabular}

c

\begin{tabular}{|c|c|c|c|c|c|}
\hline Level of variation & d.f. & SS & MS & $\%$ & $\mathbf{P}$ \\
\hline Among species & 4 & 877.6 & 219.4 & 52.66 & 0.001 \\
\hline Among populations within species & 7 & 319.7 & 45.6 & 29.28 & 0.001 \\
\hline Within populations & 55 & 254.0 & 4.6 & 16.06 & 0.001 \\
\hline
\end{tabular}

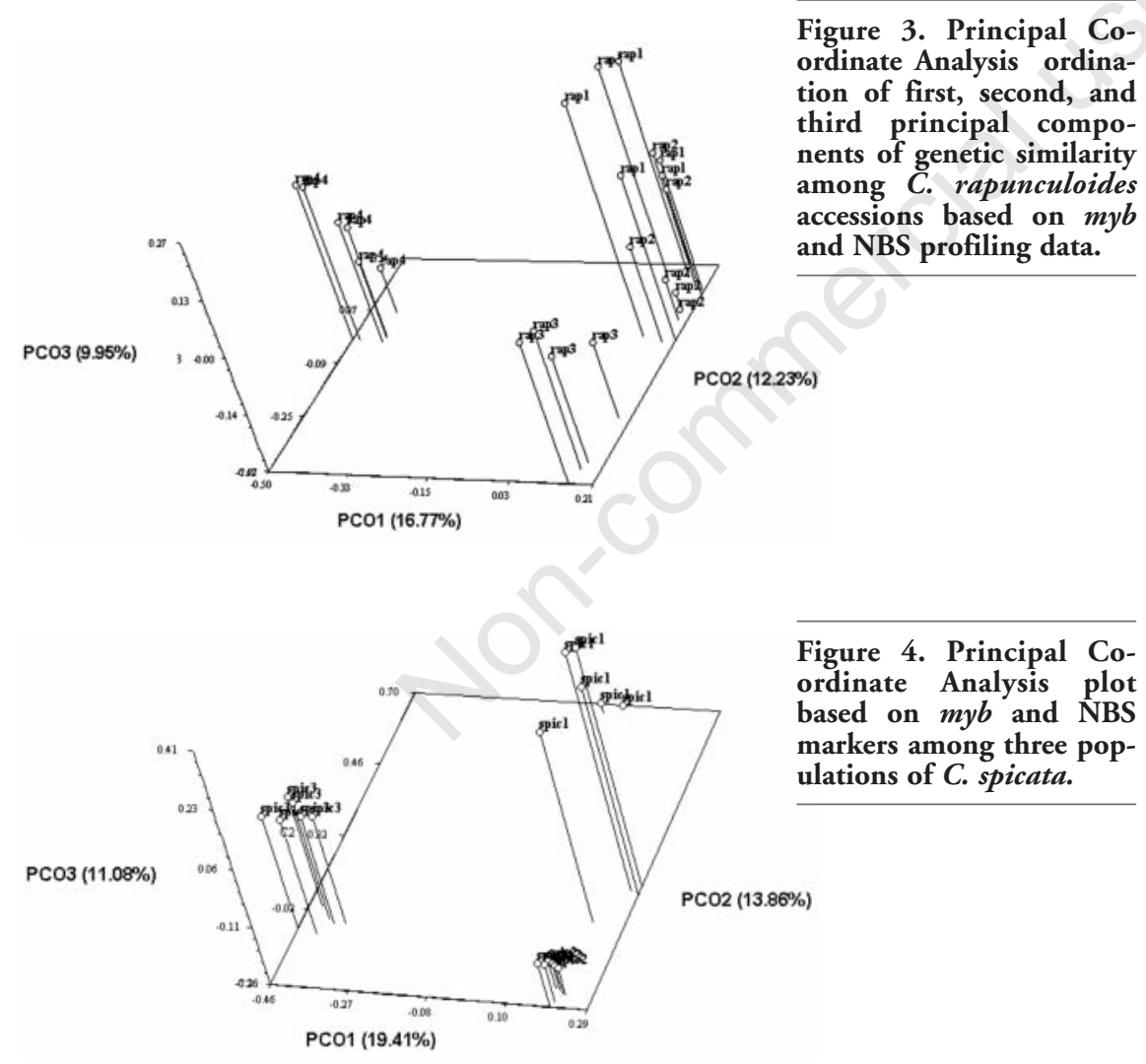

among the five species (45.19\%), among populations within species (32.54\%) and within populations (22.27\%). Looking at the single molecular marker technique, by means of $m y b$ profiling $26.55 \%$ of the total variation was attributed to differences among species, $32.11 \%$ among populations within species and the major part of variation (41.34\%) was attrib- uted to variability within populations. By means of the three NBS primer-enzyme combinations, the $52.66 \%$ of variation was attributed to differences among species, $29.28 \%$ among populations within species and $16.06 \%$ within populations.

To give a more comprehensive representation of the intra-specific relationships among the populations, we performed a PCoA on myb and NBS profiling in $C$. rapunculoides and $C$. spicata, the two species represented by more than two populations (Figures 3 and 4). PCoA yielded groupings similar to the ones obtained with cluster analysis. The first three principal co-ordinates accounted for $39.00 \%$ of the variation in C. rapunculoides and $44.35 \%$ in $C$. spicata, and differentiated the populations according to their geographical distribution. AMOVA analysis showed (Table 5) that the genetic diversity was equally attributable to differences among and within populations (49.90\% and $50.10 \%$ in C. rapunculoides; $50.53 \%$ and $49.47 \%$ in C. spicata).

\section{Structure comparison}

To investigate patterns of genetic structure, we completed a Bayesian cluster analysis using the program STRUCTURE 2.2.3. By mean of the modal value of $\Delta \mathrm{K}$, in agreement with Evanno, ${ }^{41}$ the number of groups was detected at $\mathrm{K}=9$.

Figure 5 displays the assignment probabilities of individuals in the nine inferred genetic clusters. The four populations of $C$. rapunculoides formed one structure group, Trach1 and Trach2 formed a second group, and the population of $C$. barbata formed a third. The populations of $C$. latifolia (Lat1 and Lat2) were assigned to two different structure groups. Within $C$. spicata, Spic2 and Spic3 populations, together with the $66 \%$ of Spic1, formed another group. In the Spicl population, variable levels of admixture from an unknown population were observed, showing the possible presence of hybridization. 
Table 5. Analysis of molecular variance performed on the populations of $C$. rapunculoides and C. spicata.

\begin{tabular}{llllll} 
Level of variation & d.f. & SS & MS & $\%$ & P \\
$\begin{array}{l}\text { C. rapunculoides } \\
\text { Among populations }\end{array}$ & 3 & & & & \\
$\quad$ Within populations & 18 & 197.8 & 10.9 & 50.10 & 0.001 \\
C. spicata & & & & & 0.001 \\
Among populations & 2 & 212.5 & 106.2 & 50.53 & 0.001 \\
Within populations & 15 & 223.6 & 14.9 & 49.47 & 0.001 \\
\hline
\end{tabular}

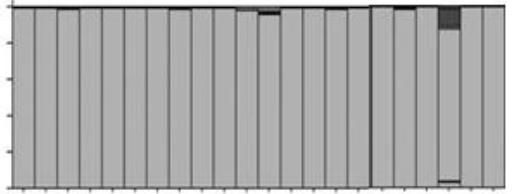

Rap1
Rap2

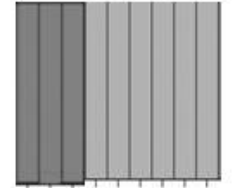

Lat1 Lat2

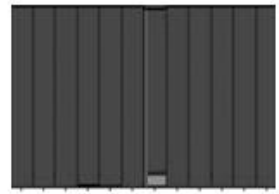

Trach1 Trach2

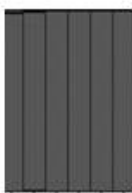

Barb

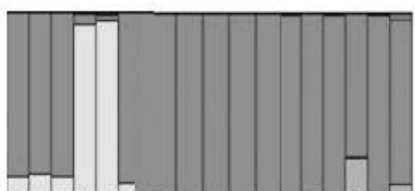

Spic1 Spic2 Spic3

Figure 5. Estimated genetic structure for $K=9$ obtained with STRUCTURE program from $m y b$ and NBS data sets. Each individual is represented by a vertical bar, which is partitioned into different colored segments that represent the individual's estimated membership fractions in nine clusters.

\section{Discussion}

The globalization of the floriculture industry is contributing to the genetic erosion process because the rapid adoption of few modern flower cultivars worldwide is rapidly replacing many traditional cultivars causing their disappearance. $^{42}$ Most ornamental plant breeding programs are focusing primarily on flower esthetic qualities and plant architecture, resulting in an inadvertent narrowing of the genetic base of many modern cultivars. With the purpose of creating an efficient gene bank to safely store a vast number of plant genera and species, the USDA Herbaceous Ornamental Crop Germplasm Committee composed a list of priority genera of herbaceous ornamentals. The genus Campanula was included in the 15 most important genera for the development of the germplasm acquisition center. $^{43}$

In contrast to the expectation that endemic plant species are genetically depauperate, it has been demonstrated that many endemic species maintain high levels of genetic variability compared to their widespread congeners. $^{44}$ In view of the preservation and exploitation in floriculture of new Campanula species with interesting ornamental values, ${ }^{31}$ the evaluation of the genetic diversity within the genus appeared necessary. In the present study, NBS and $m y b$ profiling were used for the first time for measuring genetic variation in five Campanula species ( $C$. barbata, $C$. latifolia, $C$. rapunculoides, $C$. spicata and $C$. trachelium), widespread in all the West Italian Alps. ${ }^{45}$ This research represents the first genetic investigation on these species and populations. The results can provide important information from both an ecological and a horticultural point of view.

To date, $m y b$ patterns have not been used for evaluating genetic diversity in other species while the NBS technique has been previously applied in durum wheat by Mantovani et al. ${ }^{26}$ in which it could discriminate closely related genotypes within a species. Overall, myb profiling with one enzyme - primer combination as well as NBS profiling with three different com- binations effectively distinguished Campanula genotypes. The three primer - enzyme combinations showed differences in their discriminating capacity in relation to the species.

When myb and NBS patterns were combined, Campanula species were well differentiated. The average similarity (Nei and Li coefficient) across all paired comparisons between plants revealed high genetic distance both between and within species. Supported by AMOVA, the clustering (based on combined markers) efficiently grouped the populations of the same species according to their geographical locations. Results were similar for Hypericum nummularium L. populations in the Alps, which were not true in the Pyrenees, ${ }^{46}$ or in $C$. pseudostenocodon in central-southern Apennines. ${ }^{19}$ Also, in Eryngium alpestris Schultes populations, no significant correlation was found at a geographical distance of $250 \mathrm{~km},{ }^{47}$ while in a study on Rumex nivalis Hegetschw, a correlation was found only in a large region of Switzerland. ${ }^{48}$

Results from cluster analysis of single data sets were less related to geographical distribution. In fact, we found that the $m y b$ marker was more adept at differentiating species while NBS markers were best for discriminating populations. In fact, NBS-LRR genes are responsible for the hypersensitive defence response ${ }^{49}$ demonstrated in Lolium perenne $\mathrm{L}$. in which several candida R-genes are co-located in chromosomal regions. This organization could be lead to gene rearrangement processes in accordance with new species specificity related to new pathogens.

PCoA was applied on $C$. rapunculoides and C. spicata samples to highlight the variation within species. In all two species, we found that genetic connectivity among populations decreases with increasing spatial distance: a result of natural fragmentation. Indeed, as revealed in Campanula thyrsoides L. Epilobium fleischeri Hochst., and Geum reptans L. by Kuss et al., ${ }^{50}$ the plots showed that populations grouped without overlap agreed with their geographical location as supported by AMOVA. The PCoA plot of $C$. rapunculoides genotypes clearly demarcated the differences between the four populations. In particular, the first axis separated the populations into a Maritime Alps group (Rap1, Rap2, Rap3), mainly characterized by grassland a maximum altitude of $980 \mathrm{~m}$, and a Cozie Alps group (Rap4), located in a scrub area at an altitude of $1,818 \mathrm{~m}$. The two regions were approximately $100 \mathrm{~km}$ apart. Axis 2 differentiated populations within the Maritime Alps group and also highlighted genetic dissimilarities among populations located in nearby areas. Similarly, the plot of $C$. spicata genotypes showed that the genetic variability was closely related to the habitat and geographical distances. Axis 1 differentiated populations of different valleys 
while axes 2 and 3 individualized populations collected in the same valley at different locations. Such high variability suggests that genetic connectivity between populations has a strong stochastic component at all spatial scales and that the populations are not in gene flow/drift equilibrium. ${ }^{51}$

By means of STRUCTURE software, a $\mathrm{K}$ value of 9 was obtained. Concerning $C$. rapunculoides, $C$. trachelium and $C$. barbata populations, all individuals of each species were assigned to the correct taxonomical group. In C. latifolia, Lat1 and Lat2 were allocated to two different groups (Figure 5) based on a low Nei and Li similarity value ( 0.334$)$ while in $C$. spicata, the $34 \%$ of Spicl genotypes were assigned to a completely different group. Taking into consideration that $C$. latifolia and $C$. spicata plants were sampled in a narrow area, the observed structure could be the result of fragmentation. This result confirms that the altitude associated with natural boundaries is an obstacle to gene flow, indicating that the genetic structure of plant populations reflects the interactions of various long-term evolutionary processes, such as shifts in distribution, habitat fragmentation, population isolation, mutation, genetic drift, mating system, gene flow, and selection. ${ }^{52-54}$

NBS and $m y b$ profiling showed themselves to be new and efficient techniques for studying molecular patterns of the Campanula genus, previously poorly investigated. The use of neutral markers could provide the means for a more thorough understanding of the processes that have conditioned the observed genetic structure. Because of the small size of available populations, conclusions about the Campanula species and population genetic diversity could be an useful basis from which to develop more a comprehensive work in the future.

\section{Conclusion}

In conclusion, our results highlighted that the genetic variability at $m y b$ and R-gene rich regions can be useful to assess the overall genetic diversity of plants on par with microsatellites and AFLPs ${ }^{26}$.

The high levels of genetic variability detected within and among Campanula species of the North West Alps indicate that natural fragmentation has led to a significant decline in relatedness between population pairs with increasing geographical distance, indicating the lack of a genetic bottleneck. ${ }^{55,56}$ The conservation of variability could be crucial for the continuous evolution of the species and their exploitation.

\section{References}

1. Hedrick PW. Conservation genetics: where are we now? Trends Ecol Evol. 2001;16:629636.

2. Amos W, Harwood J. Factors affecting levels of genetic diversity in natural populations. Philos Trans R Soc Lond B Biol Sci. 1998;179186.

3. Nybom H. Comparison of different nuclear DNA markers for estimating intraspecific genetic diversity in plants. Mol Ecol. 2004;13:1143-1155.

4. Bellusci F, Pellegrino G, Palermo AM et al. Genetic differentiation of the endemic orophyte Campanula pollinensis along an altitudinal gradient. Plant Biosystems. 2005;139:349-356.

5. Frazee JE, Marquis RJ. Environmental contribution to floral trait variation in Chamaecrista fasciculata (Fabaceae: Caesalpinoideae). Am J Botany. 1994;81:206215.

6. Wohlgemuth T. Environmental determinants of vascular plant species richness in the Swiss alpine zone. In: Mountain Biodiversity. A global Assessment (eds. Körner C, Spehn EM). 2002;103-116.

7. Pigliucci M. Evolution of phenotypic plasticity: where are we going now? Trends Ecol Evol. 2005;20:481-486.

8. Czesak ME, Fox CW, Wolf JB. Experimental evolution of phenotypic plasticity: how predictive are cross-environment genetic correlations? Am Nat. 2006;168:323-335.

9. Vogler DW, Peretz S, Stephenson AG. Floral plasticity in an iteroparous plant: the interactive effects of genotype, environment, and ontogeny in Campanula rapunculoides (Campanulaceae). Am J Bot. 1999;86:482494.

10. Laane MM. Cyto-ecological studies in Norwegian Campanula species. Botanical Tidsskr. 1968;63:319-341.

11. Zhukova PG. Karyology of some plants, cultivated in the arctic-alpine botanical garden. In: Plantarum in Zonam Polarem Transportatio: II. Leningrad (ed. Avrorin NA). 1967.

12. Gadella TWJ. Cytotaxonomic studies in the genus Campanula. Wentia. 1964;11:1-104.

13. Gadella TWJ. Some note on the delimitation of genera in the Campanulaceae. I. Proceedings of the Royal Dutch Academy of Science. 1966;69:502-521.

14. Laane MM. Further chromosome studies in Norwegian vascular plants. Blyttia. 1969;27: 5-17.

15. Huxley A. Campanula. In: The New Royal Horticultural Society. Dictionary of Gardening. (ed. in chief Huxley A; ed. Griffiths M; ed. managing Levy M). Four Volumes, London. 1999.

16. Sunnucks P. Efficient genetic markers for population biology. Trends Ecol Evol 2000;15:199-203.

17. Tremblay RL, Ackerman JD. Gene flow and effective population size in Lepanthes (Orchidaceae): a case for genetic drift. Biological Journal of the Linnean Society. 2001;72:47-62.

18. Turimaru T, Tomaru N, Nishimura N, Yamamoto S. Clonal diversity and genetic differentiation in Ilex leucoclada patches in an old-growth beech forest. Mol Ecol. 2003;12:809-818.

19. Bellusci F, Palermo AM, Pellegrino G,
Musacchio A. Genetic diversity and spatial structure in the rare, endemic orophyte Campanula pseudostenocodon Lac. (Apennines, Italy), as inferred from nuclear and plastid variation. Plant Biosystem. 2008;142:24-9.

20. Elameen A, Klemsdal SS, Dragland S, Fjellheim S, Rognli 0A. Genetic diversity in a germplasm collection of roseroot (Rhodiola rosea. in Norway studied by AFLP. Biochemical Systematics and Ecology. 2008;36:706-715.

21. Zhang LB, Kadereit JW. Classification of Primula sect. Auricula (Primulaceae) based on two molecular data sets (ITS, AFLPs), morphology and geographical distribution. Bot J Linn Soc. 2004;146:1-26.

22. Yu H, Li Q. EST-SSR markers from the Pacific oyster, Crassostrea gigas. Molecular Ecology Notes. 2007;7:860-2.

23. Van der Linden CG, Wouters DCA, Mihalka V et al. Efficient targeting of plant disease resistance loci using NBS profiling. Theor Appl Genet. 2004;109:384-393.

24. Calenge F, Van der Linden CG, Van de Weg E et al. Resistance gene analogues identified through the NBS-profiling method map close to major genes and QTL for disease resistance in apple. Theor Appl Genet. 2005;110:660-8.

25. Syed NH, Sørensen AP, Antonise R et al. A detailed linkage map of lettuce based on SSAP, AFLP and NBS markers. Theor Appl Genet. 2006;112:517-527.

26. Mantovani P, Van der Linden G, Maccaferri $\mathrm{M}$, et al. Nucleotide-binding site (NBS) profiling of genetic diversity in durum wheat. Genome. 2006;49:1473-1480.

27. Gu Y, Zhao QC, Sun DL, Song WQ. A genetic linkage map based on AFLP and NBS markers in cauliflower (Brassica oleracea var. botrytis). Botanical Studies. 2008;49:93-9.

28. Chen BJ, Wang Y, Hu YL, Wu Q, Lin ZP. Cloning and characterization of a droughtinducible MYB gene from Boea crassifolia. Plant Science. 2005;168:493-500.

29. Stracke R, Werber M, Weisshaar B. The R2R3-MYB gene family in Arabidopsis thaliana. Curr Opin Plant Biol. 2001;4:447456.

30. Kranz HD, Denekamp M, Greco R et al. Towards functional characterisation of the members of the R2R3-MYB gene family from Arabidopsis thaliana. Plant J 1998;16:263276.

31. Scariot V, Seglie L, Caser M, Devecchi M. Evaluation of ethylene sensitivity and postharvest treatments to improve the vase life of four Campanula species. Eur J Horticultural Sci. 2008;73:166-170.

32. Nei M, Li WH. Mathematical model for studying genetic variation in terms of restriction endonucleases. Proceedings of the National Academy of Sciences, USA. 1979;76:52695273.

33. Sneath PHA, Sokal RR. Numerical Taxonomy. Freeman, San Francisco. 1973.

34. Van de Peer Y, De Wachter Y. TREECON for Windows: A software package for the construction and drawing of evolutionary trees for the Microsoft Windows environment. Comput Appl Biosci. 1994;10:569-570.

35. Mantel N. The detection of disease clustering and generalized regression approach. Cancer Res. 1967;27:209-220.

36. Liedloff A. MANTEL V2.0, Nonparametric Test Calculator. Queensland University of 
Technology, Australia. 1999. Available from http://www.terc.csiro.au/mantel.htm.

37. Smouse PE, Long JC, Sokal RR. Multiple regression and correlation extensions of the Mantel test of matrix correspondence. Systematic zoology. 1986;35:627-632.

38. Rohlf FJ. NTSYS-pc: Numerical taxonomy and multivariate analysis system, version 2.1. Exeter Software. Setauket, New York. 2000.

39. Excoffier L, Smouse PE, Quattro JM. Analysis of molecular variance inferred from metric distances among DNA haplotypes: application to human mitochondrial DNA restrinction sites. Genetics. 1992;131:479-491.

40. Falush D, Stephens M, Pritchard JK. Inference of population structure using multilocus genotype data: dominant markers and null alleles. Mol Ecol Notes. 2007; 7:574-8.

41. Evanno G, Regnaut S, Goudet J. Detecting the number of clusters of individuals using the software STRUCTURE: a simulation study. Mol Ecol. 2005;14:2611-2620.

42. Tay D. Herbaceous ornamental plant germplasm conservation and use. Theoretical and practical treatments. In: Flower Breeding and Genetics (ed. Anderson NO). 2007;113-175.

43. Tay D. The Ornamental Plant Germplasm Center - ranking priority genera for conservation. HortScience. 2003;38:678.
44. Ellstrand NC, Elam DR. Population genetic consequences of small population size: implications for plant conservation. Annu Rev Ecol Syst. 1993;24:217-242.

45. Bernini A, Marconi G, Polani F. Campanule d'Italia e dei territori limitrofi. Verba and Scripta, Pavia, Italy. 2002.

46. Gaudeul M. Disjunct distribution of Hypericum nummularium L. (Hypericaceae): molecular data suggest bidirectional colonization from a single refugium rather than survival in distinct refugia. Biol J Linn Soc. 2006;87:437-447.

47. Gaudeul M, Taberlet P, Till-Bottraud I. Genetic diversity in an endangered alpine plant, Eryngium alpinum L. (Apiaceae), inferred from amplified fragment length polymorphism markers. Mol Ecol. 2000;9:1625-1637.

48. Stehlik I. Glacial history of the alpine herb Rumex nivali (Polygonaceae): a comparison of common phylogeographic methods with nested clade analysis. Am J Bot. 2002;89: 1007-1016.

49. Dracatos PM, Cogan NOI, Sawbridge TI, et al. Molecular characterisation and genetic mapping of candidate genes for qualitative disease resistance in perennial ryegrass (Lolium perenne L.). BMC Plant Biology. 2009;9:62-84.
50. Kuss P, Pluess AR, Egusdottir H, Stocklin J. Spatial isolation and genetic differentiation in naturally fragmented plant poluations of the Swiss Alps. Journal of Plant Ecology. 2008;1:149-159.

51. Hutchinson DW, Templeton AR. Correlation of pairwise genetic and geographic distance measures: inferring the relative influences of gene flow and drift on the distribution of genetic variability. Evolution. 1999;53:18981914.

52. Hewitt GM. Post-glacial re-colonization of European biota. Biological Journal of the Linnean Society. 1999;68:87-112.

53. Schaal BA, Hayworth DA, Olsen KM, Rauscher JT, Smith WA. Phylogeographic studies in plants: problems and prospects. Molecular Ecology. 1998;7:465-474.

54. Thompson JN. Evolutionary ecology and the conservation of biodiversity. Trends Ecol Evol. 1996;11:300-3.

55. Jelinski DE. On genes and geography: a landscape perspective on genetic variation in natural plant populations. Landscape Urban Plan. 1997;39:11-23.

56. Frankham R, Ballou JD, Briscoe DA Introduction to Conservation Genetics, Cambridge University Press, Cambridge, UK. 2002. 